INTERNATIONAL JOURNAL OF MULTIDISCIPLINARY RESEARCH AND ANALYSIS

ISSN(print): 2643-9840, ISSN(online): 2643-9875

Volume 03 Issue 12 December 2020

DOI: 10.47191/ijmra/v3-i12-04, Impact Factor: 5.522

Page No.- 285-292

\title{
What Are Enterprises' Growth Indices Implications? The Case of Food Firms Listed on the Hanoi Stock Exchange
}

\author{
Doan Thi Nguyet Ngoc ${ }^{1}$, Nguyen Dieu Linh ${ }^{2}$, To Thi Thu Trang ${ }^{3}$ \\ ${ }^{1,3}$ Faculty of Accounting, University of Labor and Social Affairs, Vietnam \\ ${ }^{2}$ The faculty of Accounting and Auditing - Banking Academy, Vietnam
}

\begin{abstract}
The study investigates growth indices of food firms listed on the Hanoi stock exchange (HNX), which is one of the basic characteristics of firm performance. The study employs a set of aggregated data from 15 food firms listed on the HNX. At the same time, the study also receives comments from experts experienced in the research field. We have performed some descriptive analysis, compared with support by software Stata 13 to evaluate and measure growth indices of food firms listed on the HNX. The results show that there is a difference in growth indices of food firms listed on the HNX. For each enterprise, there is little change in charter capital in the period 2015-2019. Firms with 10\% or more foreign ownership account for a relatively low proportion of these enterprises.
\end{abstract}

Keywords: Long-term debt growth (LDG), Liabilities growth (LG), Equity growth (EG), Charter capital growth (CG), finance JEL codes: G32, 016, P33, P45

\section{Introduction}

It is necessary not only for financial analyst but also for investors as well as the company its self and its debtors to know how to calculate and apply financial indicators in general, growth indices in particular. These indicators provide information for users to compare different aspects of financial statements in an enterprise with other firms in the industry to consider the ability to pay dividends as well as the ability to pay for debts.

Evaluating growth indices of an enterprise helps investors choose a suitable stock portfolio because investors can predict businesses' performance based on growth indices, thereby can forecast stock prices of enterprises. In addition, the assessment of growth indicators of enterprises contributes to improving business performance of enterprises.

This study analyzes the growth indices of food firms listed on the HNX by evaluating and measuring four (4) basic growth indices in food firms listed on the HNX, including: (i) Long-term debt growth (LDG); (ii) Liabilities growth (LG); (iii) Equity growth (EG) and (iv) Charter capital growth (CG).

\section{Theoretical background and literature review}

The capital structure theory of Modigliani and Miller (1958) stated that there is no relationship between the decision of debt and equity structure and the value of an enterprise. However, Modigliani and Miller (1963) affirmed, capital structure is related to the value of enterprises. The higher level of debt, the more the value of an enterprise increases and the firm value would increase to the maximum when the enterprise is financed by $100 \%$ of debt. The cost of equity of a levered firm positively increases with the debt to equity ratio (Modigliani and Miller, 1963).

The trade-off theory of Kraus and Litzenberger (1973), Myers (1884) affirmed that the reasonable combination of equity and debt will create an optimal capital structure for enterprises. This theory also mentions how much debt and equity should be financed in order to balance the cost and benefit of capital for the purpose of explaining why enterprises are often funded partly by debt and partly by equity.

The pecking order theory by Myers and Majluf (1984) concludes, asymmetric information between managers and investors affects the choice between internal and external funding, between issuance of new debt securities and equity securities. Therefore, the pecking order appears, whereby investment is financed first by internal capital, then by debt and finally by issuing new equity. 


\section{What Are Enterprises' Growth Indices Implications? The Case of Food Firms Listed on the Hanoi Stock Exchange}

Inheriting previous studies, this study uses a mixed research method to analyze growth indices of food firms listed on the HNX through the evaluation four (4) ratios in the period 2015-2019, including: (i) Long-term debt growth (LDG); (ii) Liabilities growth (LG); (iii) Equity growth (EG) and (iv) Charter capital growth (CG). The research results could contribute to analyzing the firm performance situation of enterprises and are meaningful for enterprise managers to make effective business decisions.

\section{Methodology}

Firstly, we interviewed experts who are leading lecturers in finance and accounting; financial directors in food enterprises.

After that, the study uses balance sheet data, data collected by subjects and by time - series. The secondary data collected from the audited financial statements of 15 food firms listed on HNX in operation by the end of the accounting year 2019 on such reputable website https://finance.vietstock.vn/. Thus, this study has 15 firms * 5 years $=75$ observed variables, which have been processed and cleaned with Excel.

Final, we used Stata13 software in applying quantitative research method.

Data were tested for normal distribution, used Histogram's chart, results were presented in figure 1 to figure 4.
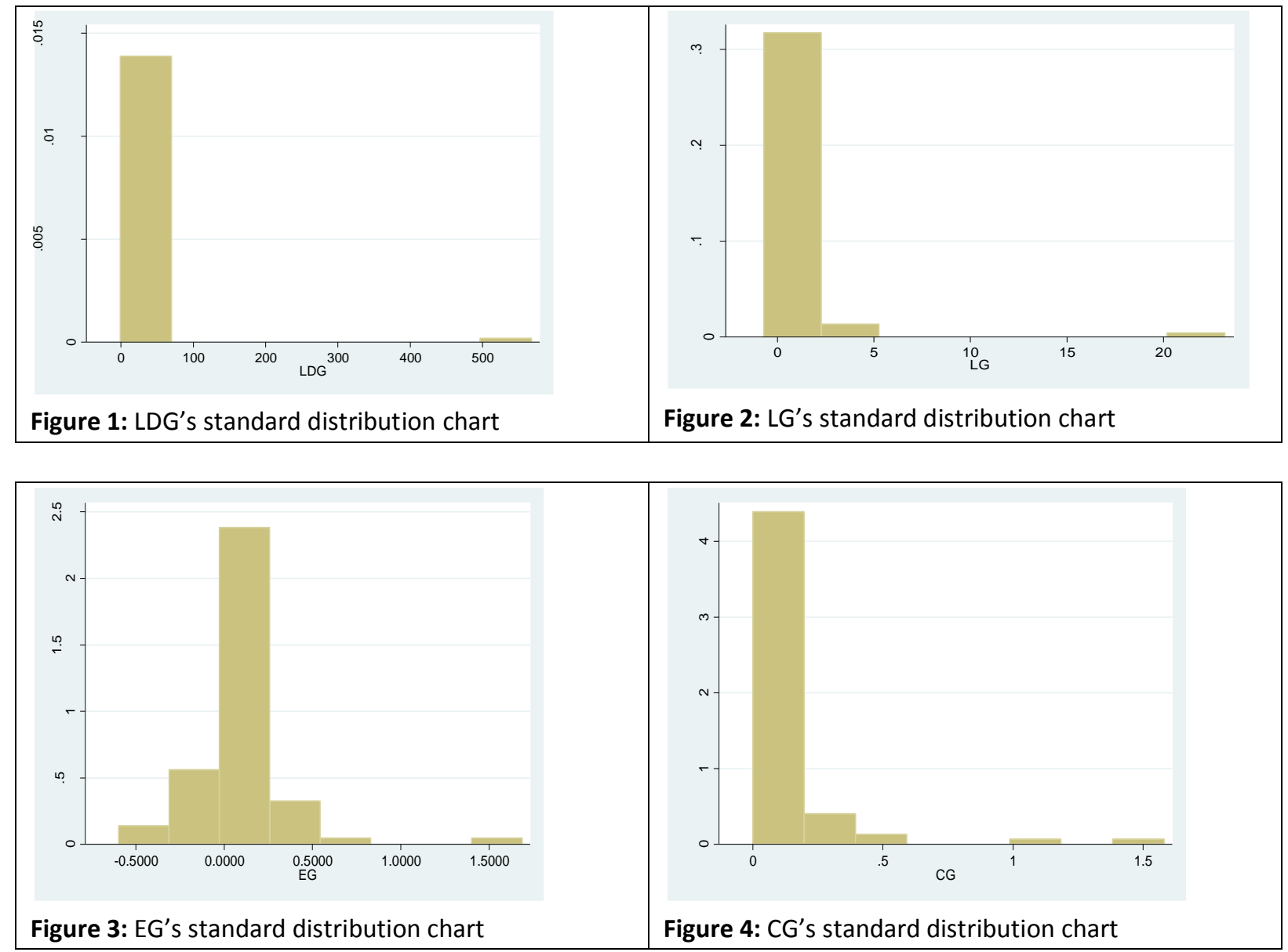

4. Research results and discussion

\subsection{Descriptive statistics results}

Table 1: General descriptive statistics of growth indices

\begin{tabular}{r|rrrrr} 
Variable & Obs & Nean & Std. Dev. & Min & Max \\
\hline LDG & 75 & 9.208833 & 65.68185 & -1 & 567.5646 \\
LG & 75 & .5404467 & 2.769623 & -.7088 & 23.1704 \\
EG & 75 & .0687413 & .2677975 & -.5982 & 1.6865 \\
CG & 75 & .0735827 & .2330064 & 0 & 1.58
\end{tabular}

Sources: Stata Sofware 13 


\section{What Are Enterprises' Growth Indices Implications? The Case of Food Firms Listed on the Hanoi Stock Exchange}

Table 1 shows: There are 4 growth indicators, each of which is described by 75 observations (obs); basic indicators such as average value (mean), maximum value ( $\max$ ), minimum value ( $\mathrm{min}$ ), standard deviation (sd) of each index have been identified and these basic indicators accurately reflect the current growth situation of food firms listed on the HNX.

Table 2: Correlation analysis results

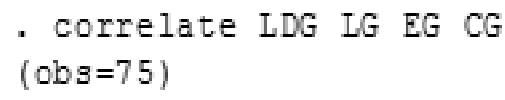

\begin{tabular}{r|rrrr} 
& LDG & LG & EG & CG \\
\hline LDG & 1.0000 & & & \\
LG & 0.0964 & 1.0000 & & \\
EG & 0.0281 & -0.0285 & 1.0000 & \\
CG & -0.0433 & -0.0219 & 0.7174 & 1.0000
\end{tabular}

Sources: Stata Sofware 13

Table 2 shows the results of correlation analysis, as known as multicollinearity analysis. The results indicate that the absolute value of each correlation coefficient between the two growth indices is less than 0.8 ; therefore, there is no multicollinearity phenomenon between the growth indicators.

Comparison the growth indicators between firms with $10 \%$ or more foreign ownership and the rest of firms.

Foreign ownership (CS): The dummy variable is 1 if the enterprise has foreign ownership participation of $10 \%$ or more. The variable for the rest of firms is zero (0).

Table 3: Comparison LDG between firms with $10 \%$ or more foreign ownership and the rest of firms.

- test LDG, by (CS)

Two-sample $t$ test with equal variances

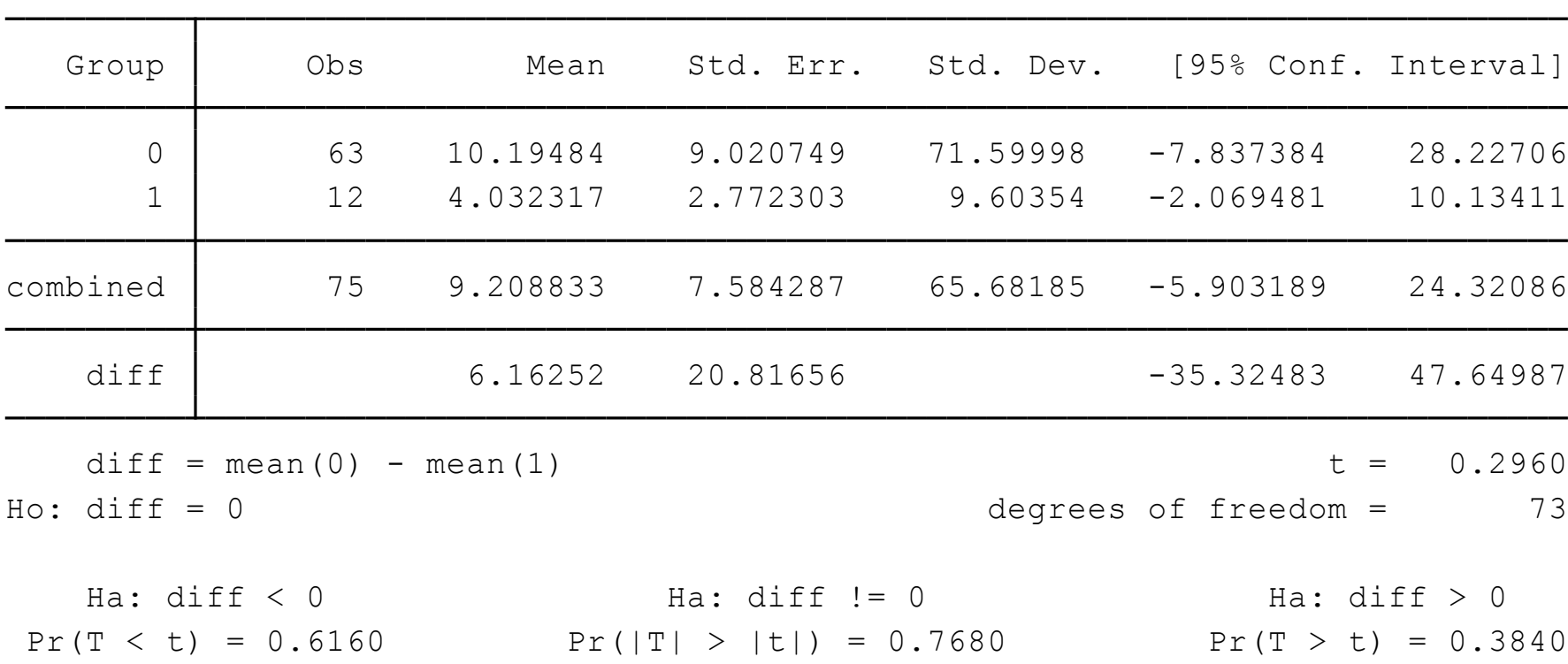

Sources: Stata Sofware 13

The results in Table 3 shows: There are 12 times of enterprises with foreign ownership participation; Enterprises with $10 \%$ or above of foreign ownership have a lower LDG than others do. However, the difference of LDG between over $10 \%$ foreign owned enterprises and the remaining enterprises is not statistically significant ( $p$-value $=0.768>0.05$, difference value 6.16252 ) 
Table 4: Comparison LG between firms with $10 \%$ or more foreign ownership and the rest of firms.

- ttest LG, by (CS)

Two-sample $t$ test with equal variances

\begin{tabular}{|c|c|c|c|c|c|c|c|c|}
\hline & Group & & Obs & Mean & Std. Err. & Std. Dev. & [95\% Conf. & Interval] \\
\hline & 0 & & 63 & .546981 & .3746531 & 2.973717 & -.2019399 & 1.295902 \\
\hline & 1 & & 12 & .5061417 & .3829499 & 1.326577 & -.3367254 & 1.349009 \\
\hline comk & bined & & 75 & .5404467 & .3198086 & 2.769623 & -.0967858 & 1.177679 \\
\hline & $\operatorname{diff}$ & & & .0408393 & .878291 & & -1.709592 & 1.791271 \\
\hline & $\operatorname{diff}$ & 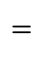 & $\operatorname{mean}(0)$ & - mean (1) & & \multirow[b]{2}{*}{ degrees } & $t=$ & 0.0465 \\
\hline Ho: & $\operatorname{diff}$ & $=$ & 0 & & & & of freedom = & 73 \\
\hline & $\mathrm{Ha}:$ & dif & $\mathrm{ff}<0$ & & Ha: diff ! & 0 & \multicolumn{2}{|c|}{$\mathrm{Ha}:$ diff $>0$} \\
\hline $\operatorname{Pr}$ & $(\mathrm{T}<$ & t) & $=0.5185$ & Pr & $\mathrm{T}|>| t \mid)=$ & .9630 & $\operatorname{Pr}(\mathrm{T}>\mathrm{t}$ & )$=0.4815$ \\
\hline
\end{tabular}

Sources: Stata Sofware 13

The results in Table 4 shows: There are 12 times of enterprises with foreign ownership participation; Enterprises with $10 \%$ or above of foreign ownership have a lower LG than others do but not significantly. However, the difference of LG between over $10 \%$ foreign owned enterprises and the remaining enterprises is not statistically significant ( $p$-value $=0.9630>0.05$, difference value $0.0408393)$.

Table 5: Comparison EG between firms with $10 \%$ or more foreign ownership and the rest of firms.

$$
\text { - ttest EG, by (CS) }
$$

Two-sample $t$ test with equal variances

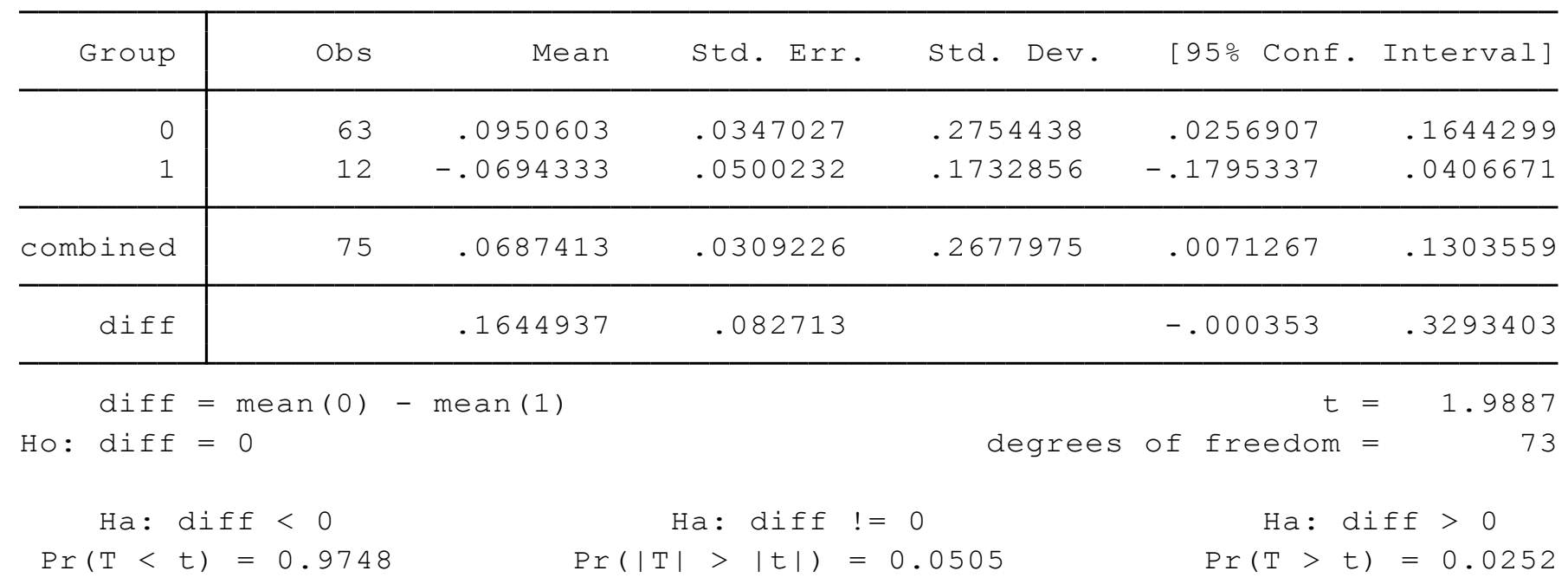

Sources: Stata Sofware 13

The results in Table 5 shows: There are 12 times of enterprises with foreign ownership participation; Enterprises with $10 \%$ or above of foreign ownership have a lower EG than others do. However, the difference of EG between over $10 \%$ foreign owned enterprises and the remaining enterprises is not statistically significant ( $p$-value $=0.0505>0.05$, difference value 0.1644937 ). 


\section{What Are Enterprises' Growth Indices Implications? The Case of Food Firms Listed on the Hanoi Stock Exchange}

Table 6: Comparison CG between firms with $10 \%$ or more foreign ownership and the rest of firms.

- ttest CG, by (CS)

Two-sample $t$ test with equal variances

\begin{tabular}{|c|c|c|c|c|c|c|}
\hline Group & Obs & Mean & Std. Err. & Std. Dev. & [95\% Conf. & Interval] \\
\hline 0 & 63 & .0875984 & .0317611 & .2520963 & .0241088 & .151088 \\
\hline 1 & 12 & 0 & 0 & 0 & 0 & 0 \\
\hline combined & 75 & .0735827 & .0269053 & .2330064 & .0199728 & .1271926 \\
\hline $\operatorname{diff}$ & & .0875984 & .0731763 & & -.0582418 & .2334386 \\
\hline
\end{tabular}

$\operatorname{diff}=\operatorname{mean}(0)-\operatorname{mean}(1)$

$t=1.1971$

Ho: diff $=0$

degrees of freedom =

Ha: diff $<0$

$\operatorname{Pr}(T<t)=0.8824$
Ha: diff $!=0$

$\operatorname{Pr}(|\mathrm{T}|>|\mathrm{t}|)=0.2351$
$\mathrm{Ha}: \operatorname{diff}>0$

$\operatorname{Pr}(\mathrm{T}>\mathrm{t})=0.1176$

Sources: Stata Sofware 13

The results in Table 6 shows: There are 12 times of enterprises with foreign ownership participation; Enterprises with 10\% or above of foreign ownership have a lower CG than others do. However, the difference of CG between over $10 \%$ foreign owned enterprises and the remaining enterprises is not statistically significant ( $p$-value $=0.2351>0.05$, difference value 0.0875984 )

4.2. Growth situation of food firms listed on HNX

Table 7: Growth indices of food firms listed on the HNX during the period 2015-2019

\begin{tabular}{|c|c|c|c|c|c|c|}
\hline Stock code & 2015 & 2016 & 2017 & 2018 & 2019 & Average \\
\hline \multicolumn{7}{|c|}{ Long-term debt growth (LDG) } \\
\hline CAN & $0 \%$ & $4.13 \%$ & $2,149.85 \%$ & $1.73 \%$ & $-38.83 \%$ & $423 \%$ \\
\hline CAP & $4,559.47 \%$ & $-97.75 \%$ & $358.42 \%$ & $-86 \%$ & $0 \%$ & $947 \%$ \\
\hline HAD & $0 \%$ & $0 \%$ & $0 \%$ & $0 \%$ & $0 \%$ & $0 \%$ \\
\hline HAT & $0 \%$ & $0 \%$ & $0 \%$ & $0 \%$ & $0 \%$ & $0 \%$ \\
\hline $\mathrm{HHC}$ & $27.15 \%$ & $17.63 \%$ & $-8.49 \%$ & $56,756.46 \%$ & $-26.17 \%$ & $11,353 \%$ \\
\hline HKB & $489.23 \%$ & $-9.79 \%$ & $-5.36 \%$ & $-99.51 \%$ & $398.85 \%$ & $155 \%$ \\
\hline KTS & $0 \%$ & $0 \%$ & $0 \%$ & $100 \%$ & $-36.42 \%$ & $13 \%$ \\
\hline MCF & $-100 \%$ & $0 \%$ & $0 \%$ & $100 \%$ & $72.73 \%$ & $15 \%$ \\
\hline NST & $-28.12 \%$ & $-65.92 \%$ & $238.64 \%$ & $-21.25 \%$ & $16.43 \%$ & $28 \%$ \\
\hline SAF & $-100 \%$ & $0 \%$ & $0 \%$ & $0 \%$ & $0 \%$ & $-20 \%$ \\
\hline SGC & $100 \%$ & $257.75 \%$ & $-2.00 \%$ & $-1.69 \%$ & $-3.02 \%$ & $70 \%$ \\
\hline SLS & $100 \%$ & $1,011.47 \%$ & $246.04 \%$ & $53.79 \%$ & $-21.34 \%$ & $278 \%$ \\
\hline THB & $2,733.63 \%$ & $-5.53 \%$ & $-8.62 \%$ & $2.42 \%$ & $7.79 \%$ & $546 \%$ \\
\hline VDL & $-36.91 \%$ & $29.58 \%$ & $66.30 \%$ & $94.38 \%$ & $-40.45 \%$ & $23 \%$ \\
\hline VTL & $-34.01 \%$ & $22.07 \%$ & $-30.70 \%$ & $-8.17 \%$ & $-33.64 \%$ & $-17 \%$ \\
\hline \multicolumn{7}{|c|}{ Liabilities growth (LG) } \\
\hline CAN & $40.54 \%$ & $-3.13 \%$ & $-4.49 \%$ & $28.25 \%$ & $29.01 \%$ & $18.04 \%$ \\
\hline CAP & $-23 \%$ & $0.88 \%$ & $45.55 \%$ & $-19.97 \%$ & $-38.11 \%$ & $-6.93 \%$ \\
\hline HAD & $20.17 \%$ & $-13.03 \%$ & $467.86 \%$ & $-34.48 \%$ & $-61.89 \%$ & $75.73 \%$ \\
\hline HAT & $216.94 \%$ & $-43.58 \%$ & $-28.09 \%$ & $5.21 \%$ & $-16.69 \%$ & $26.76 \%$ \\
\hline $\mathrm{HHC}$ & $27.13 \%$ & $7.23 \%$ & $-9.16 \%$ & $291.49 \%$ & $16.01 \%$ & $66.54 \%$ \\
\hline
\end{tabular}


What Are Enterprises' Growth Indices Implications? The Case of Food Firms Listed on the Hanoi Stock Exchange

\begin{tabular}{|c|c|c|c|c|c|c|}
\hline HKB & $91.34 \%$ & $35.28 \%$ & $-11.01 \%$ & $-14.43 \%$ & $-27.65 \%$ & $14.71 \%$ \\
\hline KTS & $-0.49 \%$ & $-70.88 \%$ & $2317.04 \%$ & $106.29 \%$ & $-38.49 \%$ & $462.69 \%$ \\
\hline MCF & $-48.90 \%$ & $29.06 \%$ & $-37.05 \%$ & $80.31 \%$ & $8.34 \%$ & $6.35 \%$ \\
\hline NST & $22.52 \%$ & $-26.42 \%$ & $-16.91 \%$ & $-20.26 \%$ & $56.17 \%$ & $3.02 \%$ \\
\hline SAF & $-22.79 \%$ & $46.55 \%$ & $-10.52 \%$ & $42.75 \%$ & $3.95 \%$ & $11.99 \%$ \\
\hline SGC & $18.09 \%$ & $49.38 \%$ & $-15.96 \%$ & $42.76 \%$ & $-5.62 \%$ & $17.73 \%$ \\
\hline SLS & $-16.50 \%$ & $113.56 \%$ & $258.33 \%$ & $87.62 \%$ & $-13.99 \%$ & $85.80 \%$ \\
\hline THB & $3.84 \%$ & $-11.06 \%$ & $34.19 \%$ & $15.22 \%$ & $-24.53 \%$ & $3.53 \%$ \\
\hline VDL & $12.91 \%$ & $-6.55 \%$ & $46.14 \%$ & $-51.12 \%$ & $90.43 \%$ & $18.36 \%$ \\
\hline VTL & $20.24 \%$ & $10.78 \%$ & $-0.07 \%$ & $-17.20 \%$ & $18.01 \%$ & $6.35 \%$ \\
\hline \multicolumn{7}{|c|}{ Equity growth (EG) } \\
\hline CAN & $4.53 \%$ & $-6.20 \%$ & $1.73 \%$ & $-6.43 \%$ & $11.22 \%$ & $0.97 \%$ \\
\hline CAP & $30.12 \%$ & $-8.18 \%$ & $-3.95 \%$ & $16.85 \%$ & $1.08 \%$ & $7.18 \%$ \\
\hline HAD & $2.27 \%$ & $2.25 \%$ & $-52.67 \%$ & $2.26 \%$ & $0.17 \%$ & $-9.14 \%$ \\
\hline HAT & $-59.82 \%$ & $-16.44 \%$ & $43.52 \%$ & $43.86 \%$ & $1.25 \%$ & $2.47 \%$ \\
\hline $\mathrm{HHC}$ & $5.99 \%$ & $47.42 \%$ & $7.68 \%$ & $11.46 \%$ & $9.87 \%$ & $16.48 \%$ \\
\hline HKB & $27.00 \%$ & $168.65 \%$ & $-11.32 \%$ & $-27.05 \%$ & $0.49 \%$ & $31.55 \%$ \\
\hline KTS & $12.59 \%$ & $7.97 \%$ & $9.22 \%$ & $0.89 \%$ & $2.31 \%$ & $6.60 \%$ \\
\hline $\mathrm{MCF}$ & $-2.69 \%$ & $1.81 \%$ & $-0.76 \%$ & $0.49 \%$ & $1.01 \%$ & $-0.03 \%$ \\
\hline NST & $-19.81 \%$ & $10.61 \%$ & $9.43 \%$ & $4.22 \%$ & $0.88 \%$ & $1.07 \%$ \\
\hline SAF & $5.74 \%$ & $9.66 \%$ & $5.52 \%$ & $8.93 \%$ & $8.55 \%$ & $7.68 \%$ \\
\hline SGC & $11.22 \%$ & $6.34 \%$ & $1.58 \%$ & $-14.13 \%$ & $18.00 \%$ & $4.60 \%$ \\
\hline SLS & $19.48 \%$ & $35.83 \%$ & $56.21 \%$ & $13.75 \%$ & $5.41 \%$ & $26.14 \%$ \\
\hline THB & $-7.36 \%$ & $-0.53 \%$ & $-28.26 \%$ & $-3.87 \%$ & $-1.79 \%$ & $-8.36 \%$ \\
\hline VDL & $18.97 \%$ & $13.14 \%$ & $3.56 \%$ & $3.78 \%$ & $1.11 \%$ & $8.11 \%$ \\
\hline VTL & $2.29 \%$ & $0.29 \%$ & $45.49 \%$ & $22.99 \%$ & $-32.12 \%$ & $7.79 \%$ \\
\hline \multicolumn{7}{|c|}{ Charter capital growth (CG) } \\
\hline CAN & $0 \%$ & $0 \%$ & $0 \%$ & $0 \%$ & $0 \%$ & $0 \%$ \\
\hline CAP & $0 \%$ & $40.00 \%$ & $0 \%$ & $0 \%$ & $10 \%$ & $10 \%$ \\
\hline HAD & $0 \%$ & $0 \%$ & $0 \%$ & $0 \%$ & $0 \%$ & $0 \%$ \\
\hline HAT & $0 \%$ & $0 \%$ & $0 \%$ & $0 \%$ & $0 \%$ & $0 \%$ \\
\hline $\mathrm{HHC}$ & $0 \%$ & $100.00 \%$ & $0 \%$ & $0 \%$ & $0 \%$ & $20 \%$ \\
\hline HKB & $27.21 \%$ & $158.00 \%$ & $0 \%$ & $0 \%$ & $0 \%$ & $37 \%$ \\
\hline KTS & $0 \%$ & $0 \%$ & $0 \%$ & $0 \%$ & $0 \%$ & $0 \%$ \\
\hline $\mathrm{MCF}$ & $0 \%$ & $0 \%$ & $0 \%$ & $34.72 \%$ & $0 \%$ & $7 \%$ \\
\hline NST & $0 \%$ & $0 \%$ & $0 \%$ & $0 \%$ & $0 \%$ & $0 \%$ \\
\hline SAF & $0 \%$ & $34.00 \%$ & $0 \%$ & $0 \%$ & $0 \%$ & $7 \%$ \\
\hline SGC & $0 \%$ & $0 \%$ & $0 \%$ & $0 \%$ & $0 \%$ & $0 \%$ \\
\hline SLS & $0 \%$ & $0 \%$ & $20.00 \%$ & $20.00 \%$ & $0 \%$ & $8 \%$ \\
\hline THB & $0 \%$ & $0 \%$ & $0 \%$ & $0 \%$ & $0 \%$ & $0 \%$ \\
\hline VDL & $15.00 \%$ & $18.00 \%$ & $0 \%$ & $0 \%$ & $0 \%$ & $7 \%$ \\
\hline VTL & $0 \%$ & $0 \%$ & $50.00 \%$ & $24.94 \%$ & $0 \%$ & $15 \%$ \\
\hline
\end{tabular}

Sources: https://finance.vietstock.vn/ and authors synthesized

The formula for calculating the growth indices are as follows:

Growth indices $A_{n \text { periods }}$

$=\frac{\frac{A_{0}-A_{1}}{\left|A_{1}\right|}+\ldots+\frac{A_{n-1}-A_{n}}{\left|A_{n}\right|}}{N}$

Source: quantri.vn 


\section{What Are Enterprises' Growth Indices Implications? The Case of Food Firms Listed on the Hanoi Stock Exchange}

In which $A_{0}$ is data of the current period. $A_{n}$ is the data of $n$ previous periods. A period can be the last 4 quarters, the most recent 1 year, the last 3 years or the last 5 years. In this study, a period is the most recent 1 year.

\section{Long-term debt growth (LDG)}

Long-term debt (LD) is the total value of long-term liabilities of the enterprise, including debts with the remaining payment term of over 12 months or more than a normal production and business cycle.

This indicator is used to evaluate the ability of enterprises to fulfill their long-term financial obligations. In addition, it also reflects the level of debts use for financing enterprise investment compared with the level of equity use.

Financial analysts are more concerned with the long-term debt situation of enterprises than the short-term debts because shortterm debts are subject to change. Thus, short - term debts do not accurately reflect the debt situation of enterprises. Therefore, indicators reflecting long-term debt ratios are often used.

Experts said that the higher this indicator, the greater the probability of the enterprise's insolvency. On the other hand, a high ratio of debt use creates benefits for businesses because interest expenses are tax deductible. Table 7 shows that enterprises with stock codes HHC and CAP have the highest LDG, so these two enterprises need to take measures to improve long-term debt situation to reduce enterprises' insolvency. Enterprises with stock codes HAD and HAT did not incur long-term debts in the period 2015-2019. Enterprises with stock codes SAF, VTL have average LDG in the period 2015-2019 were less than zero (<0).

\section{Liabilities growth (LG)}

Liabilities are debts arising in the course of enterprises' operations. Payables include loans and debts in payment. Payables are divided into short-term liabilities (debts payable by the enterprise within a year or a normal business cycle) and long-term liabilities. In favorable business conditions, the increase in liabilities implies that the degree of financial independence of the enterprise decreases, which can lead to the higher financial risks, but can facilitate the enterprise to increase the profitability of capital and vice versa.

Table 7 shows that enterprises with the stock codes KTS, SLS have high average LG in the 2015-2019 period; Enterprises with stock code NST, THB have a relatively low average LG for the period 2015-2019. Meanwhile, the enterprise with stock code CAP has very well controlled liability growth index during 2015-2019 (average LG <0).

Enterprises with a high LG level need to firstly classify and arrange debts by time (short term, long term); in which details of each payable must be listed (total, overdue debt). Enterprises also need to check the amount of debts paid in the period compared with the total amount of debts payable in the period to control the extent of debt payment, review the amount of debts that must be paid at the end of the period compared to the amount of debts payable in the period. In addition, the enterprise should pay attention to overdue debts, minimizing the overdue debts occurrence because it reflects the weak payment operations of the enterprise.

\section{Equity growth (EG)}

Table 7 shows that there is a difference in EG index of each food firm listed on the HNX. Enterprises with stock codes HKB, SLS, HHC have a higher EG than others, while enterprises with stock codes CAN and MCF have the lowest EG.

The growth of total equity is a solid basis for enterprises to increase total capital and form total assets of enterprises in the industry (Le, 2017).

Experts say that the growth in equity of enterprises is supported by profitability. In the case of a enterprise loss, it will adversely affect the capital growth of the enterprise, reduce equity level, thereby reducing the capital of the enterprise over the years.

\section{Charter capital growth (CG)}

Enterprises changing their charter capital must comply with the law provisions.

Table 7 shows that 7 out of 15 listed food firms did not change their charter capital during 2015 to 2019, including enterprises with stock codes: CAN, HAD, HAT, KTS, NST, SGC and THB. The enterprise with the stock code HKB had the highest CG in the 20152019 period because in 2016, this enterprise had a sudden increase in CG (158.00\%).

\section{Conclusion}

Growth index is one of the most significant indicators to shareholders and investors to consider how much an enterprise is worth and allow creditors to predict the payment ability of current debts and evaluate additional debts if any.

In order to continuously develop and fairly compete with FDI enterprises, food firms listed on the HNX must not only ensure appropriate growth targets, but also ensure other factors including capital, technology, management qualifications, etc.

\section{References}

1) Kraus, A., \& Litzenberger, R. H. (1973). A state-preference model of optimal financial leverage. Journal of Finance, 28(4), 911-922. https://doi.org/10.1111/j.1540-6261.1973.tb01415.x 
What Are Enterprises' Growth Indices Implications? The Case of Food Firms Listed on the Hanoi Stock Exchange

2) Le, D. B. (2017). Factors affecting equity accumulation in small and medium enterprises in Vietnam's processing and manufacturing industries. Journal of research economic, 2, 63-71. [Vietnamese]

3) Modigliani, F., \& Miller, M. H. (1958). The Cost of Capital, Corporation Finance and the Theory of Investment. The American Economic Review, 48(3), 261-297

4) Modigliani, F., \& Miller, M. H. (1963). Corporate Income Taxes and the Cost of Capital: A Correction. The American Economic Review, 53(3), $433-443$.

5) Myers, S. C. (1984). The Capital Structure Puzzle. Journal of Finance, 39, 581 - 582.

6) Myers, S. C., \& Majluf, N. S. (1984). Corporate Financing and Investment Decisions when Firms have Information the Investors do not have. Journal of Financial Economics, 13(2), $187-221$.

7) Web: https://finance.vietstock.vn/; cafef.vn. 